\title{
EL ARCA DE LOS DONES
}

\section{Juan Carlos MESTRE}

\section{A José Enrique Martínez, don entre los dones}

Mi alma es esa casa de madera que arrastra el vendaval.

A veces en la noche yo siento acercarse a un huésped invisible y oigo girar su llave y escucho avanzar sus pasos.

Entonces la poesía, cada pluma arrancada a las alas de un ángel, es la semejanza de una casa en el aire, el portal luminoso, las ventanas abiertas, el que empuja la puerta y el que entra seguro y se acerca hasta el arca y reparte los dones.

Doy al amanecer, cuando la sangre de los delfines se derrama lentamente sobre el serrín de las cervecerías, un cuchillo blanco.

Al que bajo el hielo negro de la noche caminó conmigo y sufrió conmigo la dócil alianza del fracaso, dejo la herida.

A la columna de silencio de esa muchacha que rozada por el tacto de la obediencia guarda en su pensamiento la perfección de la muerte, una copa de viento y de raíces.

Al río de mi infancia donde bebió Demócrito de Siracusa la niebla del espíritu, la claridad que ya no tendrán mis ojos.

A la ciudad que cercada por la elipse del envejecimiento enterró su memoria junto a las norias de la desposesión, una tumba vacía.

Al muchacho judío que ante un espejo empañado contempla el rubí de su alma atravesado por la espina de la crucifixión, una caja de música. 
A la sombra de mi padre contemplando la Luna, una cabaña en el bosque.

$\mathrm{Al}$ que en los atrios de la conformidad padeció la pobreza mas no será nombrado en las tablas de la justicia, la balanza con los alimentos.

A la orilla del mar, un caballo con cabeza de tortuga romana.

A la mujer que me amó con la fidelidad del astrónomo, dejo el resplandor, el halo de una estrella cuyo astro no existe.

Al ibis, la analogía de las agujas.

Para el que estrechamente vigilado por la locura hizo vibrar el ángulo recto de las constelaciones, el acordeón y las palomas verdes de la plaza.

Para ti, amor mío, el río eterno de los dioses y sus gatos sagrados.

$\mathrm{Al}$ insobornable enemigo cuya víctima fue feliz como un imán vertiginoso ante los filamentos de la melancolía, una silla de enea.

A la muerte, una puerta abierta.

Al ajusticiado en el abismo de su propia escritura que solo tuvo oídos para el ángel y amó la semejanza y la inutilidad de las cosas, una jaula con peces de madera.

$\mathrm{Al}$ otoño, la lejana memoria de las ballenas del cabo.

A la sabiduría de los profetas, un candil de silencio.

A la lápida de Leonardo Mestre, los sueños que no tuvo y que ya nunca sabrá.

Al que con su linterna de fósforo ayudó a resistir y guió la navegación de los torturados, el faro de la utopía.

A la dulce mujer que se acercó a mi sombra como madre, el azul de mayo y el zumbido de las abejas en la primavera.

Al jardín de los monasterios, la alondra del alba y la rosa cortada del rabino. 
Al tetrarca y al que está detrás de su lengua como un tábano, la urna rota del centauro ante la que un lacayo da voces.

A la tristeza que iba cruzando el puente aquella tarde de invierno, un revólver cerrado por un nudo.

Para el leñador que derribó el gran ciprés de los hermeneutas, el meteoro silvestre de las ciervas ingrávidas.

A la estatua de Francesco Orsini duque de Bomarzo, el vértigo transparente de la materia que huye.

A los versos que no escribí, un collar de frutos y semillas.

A la grieta del eremita, la pantera del anochecer.

A la memoria, la lluvia, el lirio de las estaciones abandonadas por las que pasa el ferrocarril sin detenerse.

A los amantes que descifran su desnudez en la oscuridad, un hilo de saliva.

A la pirámide del conocimiento, la amatista mojada del escarabajo y los élitros celestes del jeroglífico.

A La Habana de mis antepasados allá por mil novecientos veinte, la nieve.

Para Rousseau el Aduanero, los ágiles antílopes que cruzan el agua encarnada de los sueños.

Dad este libro a los animales, al búho y al alce, al armadillo y al erizo silvestre.

Arrancadle una a una sus páginas y dádselas a los animales. Dadle al hurón la oscuridad de la palabra búfalo y al búfalo la inmaculada pradera del billar de los bares.

Y de entre todos los dones y de entre todos los sueños, dadle a mi corazón una casa en el aire. 